\title{
The Attitudes of University Students' Regarding Physical Education and Sports Lesson
}

\author{
Vahdet Alaeddinoglu \\ Horasan Vocational School, Ataturk University, Erzurum, Turkey \\ Study Area: Erzurum, Turkey \\ Coordinates: $39.90290^{\circ} \mathrm{N} ; 41.25284^{\circ} \mathrm{E}$
}

Key words: Motor skill, Motor development"

\section{Abstract}

The sample group consists of 125 volunteer students $(23$ female and 102 male). In order to collect data for the research, a survey opinion study was conducted. Physical Education and Sports Attitude Scale were used as the survey method. The first part of the survey consists of demographic features while the second part consists of questions regarding Physical Education and Sports attitude. In the study, frequency analysis was utilized to determine the demographic characteristics of the participants and the percentages of the answered questions. It was seen that the attitudes of first-grade students towards Physical Education and Sports class were significant, and the attitudes of individuals with low family income were more significant.

biggest aim of Basic Contemporary education is to provide solutions that will pave the way for multi-directional development of the individual and thus the society (Demirhan \& Altay, 2001).

Among the aims that are suitable for contemporary education practices are to offer principles that will ensure its development as a whole with its mental, emotional, personal, and social aspects. The emotional and mental development of individuals will therefore lead the way for their physical development. It supports the development of movement by activating the mental processes with discovery, perception, and interpretation which are inherent elements of human nature. Naturally, movement development creates a system where individuals can become aware of themselves by training their body (Kangalgi?l et al., 2006).

At this point, Physical Education and Sports form an attitude in individuals. Being occasionally negative, such attitudes mostly come in form of positive attitudes. Attitudes are either congruence or overlapping of the previously existing knowledge of the individual with the newly formed knowledge. If the attitude is positive about a situation or an event, the individual's emotions of loyalty, love, and sense of belonging can actively manifest. However, negative attitudes may appear as avoidance, alienation hate, and isolation from the event or the situation (Demirhan \& Altay, 2001).

Physical Education and Sports make great contributions to social structures. Especially with the

*Corresponding Author:v.alaeddinoglu@atauni.edu.tr 
development of technology, there emerged a great need for sports and active living. At this point, Physical Education and Sports provide physical health and metal health to its participants, which facilitates social harmony in terms of training, sportive activity, movement development, and competition (Sirinkan \& Gündogdu, 2011).

Physical Education and Sports, unlike all other education branches, make great contributions to individuals in physical, spiritual, and mental aspects and can be utilized as an active complement to other educational programs. As a matter of fact, there are many studies on such phenomena in the literature, especially because it is a factor that supports the development of children and increases their movement and mental capacity. Such studies vary in terms of focus, as they can be mental structure, movement and physical capacity or sociology oriented, or concerned about many other multi disciplinary fields. Considering that the individual cannot be independent of the society, studies have been mainly conducted to understand the attitudes, perceptions, and orietations of individuals (Celik \& Pulur, 2011). A sportive and active life improves both the physical and mental health of the individual. Therefore, Physical Education and Sports are among the indispensable basic elements in both social, economic, and educational fields. Moreover, sports are the most important support element that not only contributes to the psycho-social development of the individual but also enables individuals to realize their abilities (Yetim, 200o).

Physical Education and Sports undertakes very significant tasks in order to bring together many positive factors such as academic success, decision-making, resisting failure, task awareness, being a team, providing solutions to unknown and uncertain situations, and many more. In addition, a sportive and active life includes many factors that develop the individual as a whole. Thus, it is closely related to many disciplines (Akandere et al., 2010).

In conclusion, the purpose of Physical Education and Sports, which constitutes a considerable part of education, is considered as the development of the individuals as a whole and their contribution to society. In order to achieve such goals, it contribute to the development of society by utilizing sports education in all areas of education. Physical Education and Sports should be seen as the most important development program that should be included and researched at every level of educational programs in terms of contributing to the development of both the individual and the society (Gürbüz, 2011).

\section{Materials and Methods:}

SPSS 22.00 statistical package program was used for statistical analysis of the obtained data. The results were evaluated at $\mathrm{P}<0.05$ significance level. As a result of analyses conducted to understand the suitability of the data collected in the study for normal distribution, the values of
Skewness-Kurtosis and Kolmogorov-Smirnov for the scores of all variables were found to be meaningless at the importance level of $p>0.05$. These findings show that the data collected from all the tests applied matches the normal distribution. As a result, parametric analysis in groups exceeding 30 and nonparametric analysis in groups below 30 was applied in the analysis of the research data. As Analyses, t-test, Mann Whitney U test, Kruskal-Wallis H test was used.

\section{Results:}

Table 1. Posttest dynamic balance and reaction time mean and standard deviation values of all groups

\begin{tabular}{|c|c|c|c|}
\hline Parameters & Subparameters & $\mathrm{n}$ & $\%$ \\
\hline \multirow[t]{3}{*}{$\overline{\text { Age }}$} & $17-20$ years & 35 & 28.0 \\
\hline & 21-24 years & 86 & 68.8 \\
\hline & 25 years and older & 4 & 3.2 \\
\hline \multirow[t]{2}{*}{ Gender } & Man & 102 & 81.6 \\
\hline & Woman & 23 & 18.4 \\
\hline \multirow[t]{2}{*}{ Section } & Private Security & 42 & 33.6 \\
\hline & Civil Defence \& Fire Service & 83 & 66,4 \\
\hline \multirow[t]{2}{*}{ Class } & Class 1 & 43 & 34,4 \\
\hline & Class 2 & 82 & 65,6 \\
\hline \multirow{5}{*}{$\begin{array}{l}\text { His mother's } \\
\text { attitude to him }\end{array}$} & Extreme Release & 4 & 3,2 \\
\hline & Normal & 70 & 56,0 \\
\hline & Over protective & 37 & 29,6 \\
\hline & Authoritarian & 12 & 9,6 \\
\hline & Irrelevant & 2 & 1,6 \\
\hline \multirow{5}{*}{$\begin{array}{l}\text { His father's attitude } \\
\text { to him }\end{array}$} & Extreme Release & 5 & 4,0 \\
\hline & Normal & 71 & 56,8 \\
\hline & Over protective & 28 & 22,4 \\
\hline & Authoritarian & 17 & 13.6 \\
\hline & Irrelevant & 4 & 3.2 \\
\hline \multirow{4}{*}{$\begin{array}{l}\text { Family income } \\
\text { status }\end{array}$} & Bad & 5 & 4.0 \\
\hline & Middle & 85 & 68.0 \\
\hline & Good & 31 & 24.8 \\
\hline & Very good & 4 & 3.2 \\
\hline \multirow{5}{*}{$\begin{array}{l}\text { Educational status } \\
\text { of the mother }\end{array}$} & Primary & 97 & 77.6 \\
\hline & Secondary & 25 & 20.0 \\
\hline & Associate degree & 1 & .8 \\
\hline & License & 1 & .8 \\
\hline & $\mathrm{MSc} / \mathrm{PhD}$ & 1 & .8 \\
\hline \multirow{5}{*}{$\begin{array}{l}\text { Educational status } \\
\text { of father }\end{array}$} & Primary & 73 & 58.4 \\
\hline & Secondary & 38 & 30.4 \\
\hline & Associate degree & 6 & 4.8 \\
\hline & License & 5 & 4.0 \\
\hline & $\mathrm{MSc} / \mathrm{PhD}$ & 3 & 2.4 \\
\hline
\end{tabular}

The status of the attitudes of those included in the study towards physical education and sports were Neutral attitude $=14(11.2 \%)$; Positive attitude $=60(48.0 \%)$; Most positive attitude $=51(40.8 \%)$.

The differences in attitudes towards physical education and sports according to the demographic variables of the participants in the study are given in Table-2.

The Kruskal-Wallis $\mathrm{H}$ value of the difference between the participants in the study in terms of their age and attitudes towards physical education and sports was found 
to be insignificant at the $\mathrm{p}>0.05$ significance level. These findings show that there is no difference between the participants in the study in terms of their age and attitudes towards physical education and sports.

Table 3. Differences in terms of attitudes towards physical education and sports according to demographic variables

\begin{tabular}{lcccc}
\hline Features & (Test and P) & & \\
Of variable & $\mathrm{N}$ & Mean & S.S & Rank \\
\hline
\end{tabular}

\begin{tabular}{|c|c|c|c|c|}
\hline \multicolumn{5}{|l|}{ Age $(K W=.181 ; p=.913)$} \\
\hline 17-20 years & 35 & 90.80 & $13 \cdot 575$ & 62.60 \\
\hline 21-24 years & 86 & 90.33 & 14.475 & 63.50 \\
\hline 25 years and older & 4 & 84.25 & 22.692 & $55 \cdot 75$ \\
\hline \multicolumn{5}{|l|}{ Gender $(U=1156.000 ; p=.914)$} \\
\hline Man & 102 & 90.25 & 15.192 & 63.17 \\
\hline Woman & 23 & 90.35 & 10.581 & 62.26 \\
\hline \multicolumn{5}{|l|}{ Section $(t=.960 ; p=.339)$} \\
\hline Private Security & 42 & 88.52 & $15 \cdot 301$ & - \\
\hline Civil Def. \& Fire Service & 83 & 91.14 & 13.962 & - \\
\hline \multicolumn{5}{|l|}{ Class $(\mathrm{t}=3.471 ; \mathrm{p}=.001)$} \\
\hline Class 1 & 43 & 96.19 & 12.831 & - \\
\hline Class 2 & 82 & 87.16 & 14.299 & - \\
\hline \multicolumn{5}{|c|}{ His mother's attitude to him $(\mathrm{KW}=8.432 ; \mathrm{p}=.077)$} \\
\hline Extreme Release & 4 & 87.75 & 10.595 & 55.75 \\
\hline Normal & 70 & 90.80 & 15.114 & $64 \cdot 34$ \\
\hline Over protective & 37 & 92.62 & 13.925 & 70.55 \\
\hline Authoritarian & 12 & 82.08 & 11.697 & 39.63 \\
\hline Irrelevant & 2 & 82.00 & .000 & 31.00 \\
\hline His father's attitude to him & $(\mathrm{KW}$ & 5.366; $\mathrm{p}=$ & 73) & \\
\hline Extreme Release & 5 & 99.40 & 12.157 & 85.60 \\
\hline Normal & 71 & 91.32 & 14.541 & $65 \cdot 36$ \\
\hline Over protective & 28 & 85.96 & 13.999 & $53 \cdot 36$ \\
\hline Authoritarian & 17 & 88.41 & 15.293 & 56.91 \\
\hline Irrelevant & 4 & 98.00 & 3.464 & 86.25 \\
\hline \multicolumn{5}{|c|}{ Family income status $(\mathrm{KW}=12.058 ; \mathrm{p}=.007)$} \\
\hline Bad & 5 & 96.80 & 10.035 & 78.30 \\
\hline Middle & 85 & 91.38 & 14.578 & 65.62 \\
\hline Good & 31 & 90.19 & 10.242 & 60.97 \\
\hline Very good & 4 & 59.00 & 6.928 & 4.00 \\
\hline \multicolumn{5}{|c|}{ Educational status of the mother $(\mathrm{KW}=5.917 ; \mathrm{p}=.205)$} \\
\hline Primary & 97 & 90.48 & 13.961 & 63.93 \\
\hline Secondary & 25 & 89.76 & 15.736 & 60.68 \\
\hline Associate degree & 1 & 71.00 & 0.000 & 11.50 \\
\hline License & 1 & 114.00 & 0.000 & 121.00 \\
\hline $\mathrm{MSc} / \mathrm{PhD}$ & 1 & 77.00 & 0.000 & 24.00 \\
\hline \multicolumn{5}{|c|}{ Educational status of Father $(K W=7.368 ; \mathrm{p}=.118)$} \\
\hline Primary & 73 & 91.04 & 15.085 & 66.15 \\
\hline Secondary & 38 & 89.34 & 12.889 & 59.13 \\
\hline Associate degree & 6 & 93.67 & 13.201 & 69.67 \\
\hline License & 5 & 94.60 & 13.031 & 69.20 \\
\hline $\mathrm{MSc} / \mathrm{PhD}$ & 3 & 69.00 & 6.928 & 11.67 \\
\hline
\end{tabular}

The $U$ value of the difference between the participants in the study in terms of their attitudes towards physical education and sports in terms of their gender was found to be insignificant at the $\mathrm{p}>0.05$ significance level. These findings show that there is no difference between the participants in the study in terms of their attitudes towards physical education and sports in terms of their gender.
The t-test value of the difference between the participants in terms of their attitudes towards physical education and sports was found to be insignif icant at the p> 0.05 signif icance level. These findings show that there is no difference between the participants in the study in terms of their attitudes towards physical education and sports in terms of their departments.

The t-test value of the difference between the participants in terms of their attitudes towards physical education and sports in terms of their classes was found to be significant at $\mathrm{p}<0.05$ signif icance level. These findings show that there is a difference in favour of the first-grade students in terms of attitudes towards physical education and sports according to the class levels of the study participants.

The Kruskal-Wallis value of the difference between the participants in the study in terms of their mother's attitude towards herself in terms of attitudes towards physical education and sports was found to be insignificant at p> 0.05 signif icance level. These findings show that there is no difference between the participants in the study in terms of their perception of the mother's attitude towards herself, in terms of attitudes towards physical education and sports.

The Kruskal-Wallis $\mathrm{H}$ value of the difference between the participants in the study in terms of the perception of their father's attitude towards him and their attitudes towards physical education and sports was found to be insignif icant at $\mathrm{p}>0.05$ signif icance level. These findings show that there is no difference between the participants in the study in terms of their perception of their father's attitude towards him and their attitudes towards physical education and sports.

\section{Discussion:}

Each student develops a different style of participation in school sports and physical education lessons. Depending on the character of the student, 5 different levels of participation can be observed in general. While one group of students steps forth with a dominant character, another group displays a sub-macho attitude. Another group exhibits a good student profile and actively participates in the lesson. On the other hand, the other two groups may consist of timid-minded, introverted individuals. The active participation of these groups and the positive development of their attitudes are largely determined by the Physical Education and Sports teachers, their school friendships, social structures, and the lesson strategies chosen by the teacher. Besides, many other factors can affect such a situation positively or negatively. These factors need to be adjusted very well for education to reach its true purpose. Each factor should be planned and applied to complement another factor (Griffin, 1985; Ozkara, 2019).

Academic studies show that the addition of Physical Education and Sports lessons to school curricula does not affect the academic performance of primary school 
students negatively; on the contrary, it affects them positively. However, it has been observed that a time limitation is imposed by educational institutions in the course hours of these lessons, considering that the time allocated to Physical Education and Sports lessons will cause a decrease in the hours of other academic lessons (Aydin et al., 2017). The relative and indirect contributions of sports education to academic achievement and performance indicators have been proven by researches. Many studies show that academic performance and sportive performance have a positive correlation. Struggle, offering solutions, health, discipline, and many other features inherent in sports can also be reflected in academic life. In this sense, the success of students can be improved through effective and appropriate adjustment, of course, hours in school curricula and educational programs. Especially in studies conducted on weight-lifters, wrestlers, combat athletes, and other sports branches, it has been observed that individuals' characteristics such as self-esteem, aggression assertiveness, and psycho-social behaviors, are positively affected and developed by sportive life (Trudeau \& Shephard, 2008; Yigit et al., 2019). Acknowledged researchers, teachers, and educational institutions should coalesce for the establishment and comprehensive realization of the right planning which will pave the way for a combination of sports curriculum with academic curriculum. Problems of modern-day such as unhealthy life, drug addiction, malnutrition, and more can be transformed from negative issues into positive attitudes, by including sports practices in all areas of life (Bendíková, 2014).

In many countries of the world, no policy in the field of Physical Education and Sports has been determined and many educational institutions have exempted students from Physical Education and Sports. Instead, they planned sports practices as out-of-school activities. While some states in the USA contributed to the development of both their teachers and students by evaluating the Physical Education and Sports lesson as an active opportunity, some states have behaved the opposite. It has been observed in the states who have adopted the former approach that students show great improvement in academic achievement, sense of belonging, and personality development. Moreover, European countries such as Norway, Denmark, and Sweden have supported both academic achievement and physical development by integrating games and sports practices into all levels of education (Lee et al., 2007).

Especially in all levels of primary education, secondary education, and higher education institutions, physical education and sports activities play a very important role in motor skill development, talent development, positive behavior acquisition, and the ability to continue sports as a lifestyle in the future. In the EUROFIT tests conducted to observe the development of students in schools, very significant differences between students who participated in the activities and those who did not were determined. Significant statistical differences were found in students' balance, stretching ability, long jump, and running values. Upon implementation of a new, adaptive 8-week education program, a great increase in physical, mental, and psychological reaction times in children was observed (Yenal et al., 1999; Sarikaya et al., 2017).

\section{Suggestions:}

Our recommendations based on the research are as follows;

- Physical Education and Sports lesson, which has been proven by researches that it has an impact on academic success, should begiven as a lesson in all departments.

- They have a more positive attitude towards university science Physical Education and Sports lessons coming from lowincome families. Therefore, Physical Education and Sports can be used as a tool to achieve social balance.

- Physical Education and Sports lesson in the 1st grade of universities can be used as a positive motivation source on students. This situation may positively affect their academic success in the following years.

- Physical Education and Sports lesson is not only a motivational tool, but also should be re-evaluated on personality change and developed by researchers with different methods.

- It should be taken to a different level with traditional theories depending on the technology.

- A lesson should be prepared in which motor skills as well as skills can be developed together.

- The research can provide more meaningful results with more samples.

\section{References:}

Akandere, M., Özyalvaç, N.T. \& Duman, S. (2010): Ortaögretim Ögrencilerinin Beden Egitimi Dersine Yönelik Tutumlari Ile Akademik Basari Motivasyonlarinin Incelenmesi (Konya Anadolu Lisesi Örnegi). Selçuk Üniversitesi Sosyal Bilimler Enstiütüsü Dergisi, 24(1):1-10.

Aydin, E., Celik, A. \& Bas, M. (2017): Beden Egitimi Ögretmen Adaylarinin Iletisim Beceri Düzeylerinin Bazi Degiskenlere Göre Incelenmesi. Stratejik ve Sosyal Arastirmalar Dergisi, $1(1): 25-34$.

Bailey, R., Kathleen, A., David, K., Jess, M., Ian, P., Sanford, R. \& BERA (2009): The educational benef its claimed for physical education and school sport: an academic review. $\underline{\text { Res. Papers }}$ InEdu., 24(1):1-27.

Bendíková, E. (2014): Lifestyle, Physical and Sports Education and Health Benef its of Physical Activity. Eu. Res. Int. Multidisc. J., 69.

Celik, Z. \& Pulur, A. (2011): Orta Ögretim Ögrencilerinin Beden Egitimi ve Spora Iliskin Tutumlari. Ulusal Beden Egitimi ve Spor Ögretmenleri Kongresi, Van Y.Y.Ü Egitim Fakültesi Dergisi, Özel Sayi, :115-121.

Demirhan, G. \& Altay, F. (2001): Lise Birinci Sinif Ögrencilerinin Beden Egitim ve Spora Iliskin Tutum Ölçegi II. Spor Bilimleri Dergisi, 12(2):9-20.

Gürbüz, A. (2011): Ilkögretim Ikinci Kademe Ögrencilerinin Beden Egitimi ve Spor Dersine Iliskin Tutumlarinin Incelenmesi 


\section{ORIGINAL ARTICLE}

(Mugla Il Örnegi). Mugla Üniversitesi Sosyal Bilimler Enstitüsü Beden Egitimi Ve Spor Anabilim Dali Yüksek Lisans Tezi, :9-14.

Griffin, P.S. (1985): Boys' Participation Styles In A Middle School Physical Education Team Sports Unit. L. Teach. Phy. Edu., 4(2):100-110.

Kangalgi.l, M., Hünük, D. \& Demirhan, G. (2006): Ilkögreti·m, Li·se Ve Üni.versi.te Ögrenci-leri-ni·n Beden Egi.ti·mi- Ve Spora Ili-ski-n Tutumlarinin Karsilastirimasi. Spor Bilimleri Dergisi Hacettepe J. Sport Sci., 17(2):48-57.

Lee, S.M., Burgerson, C.M., Fulton, J.E. \& Spain, C. (2007): Physical Education And Physical Activity: Results From The School Health Policies And Programs Study. L. School Health, 77(8):435-463.

Ozkara, A.B. (2019): Spor Lisesi Ögrencilerinin Girisimcilik Yeterliliklerinin Incelenmesi. MANAS Sosyal Arastirmalar Dergisi, 8(1):1339-1347.

Sarikaya, M., Selçuk, M., Gencer, Y.G., Temur, H.B. \& Öntürk, U. (2017): The Effect of 8 Week Tennis Technical Training and Games On Reaction Time In 10-12 Years Old Boys. Eu. J. Phy. Edu. Sport Sci., 3(12):470-477.
Ambient Science, 2020: Vol. 07(Sp1); 165-169 DOI:10.21276/ambi.2020.07.sp1.oa20

Sirinkan, A. \& Gündogdu, K. (2011): The Perceptions of Teachers in Relation to Physical Education Curriculum and Instructional Plans. Elementary Edu. Online, 10(1):144-159.

Trudeau, F. \& Shephard, R. (2008): Physical Education, School Physical Activity. School Sports And Acad. Perf. Int. J. Behavior. Nutr. Phy. Activity, 5(10):1-12.

Yenal, T.H., Çamliyer, H. \& Saracaloglu, A.S. (1999): Ilkögretim Ikinci Devre Çocuklarinda Beden Egitimi Ve Spor Etkinliklerinin Motor Beceri Ve Yetenekler Üzerine Etkisi. Gazi Beden Egitimi ve Spor Bilimleri Dergisi, 4(3):15-24.

Yetim, A. (2000): Sporun Sosyal Görünümü. Gazi Beden Egitimi Ve Spor Bilimleri Dergisi, 1:63-72.

Yigit, S.M., Yilmaz, T., Acar, E. \& Dalbudak, I. (2019): An Investigation Of Self And Aggression Levels Of Weightlifters. Int.J.Appl. Exer. Physiol., 8(3):84-90. 